\section{Corporate Strategies and the Clean Development Mechanism}

\section{Developing Country Financing for Developed Country Commitments?}

Søren Ender Lütken, Affiliated Researcher, Institute for Production, Aalborg University, Denmark and Axel Michaelowa, Department of Political Science, University of Zurich, Switzerland and Perspectives Climate Research, Germany

Mechanism (CDM) of the Kyoto Protocol. It explains why, instead of the expected bilateral structure where a company from an industrialized country invests in a project in a developing country and receives the emission reduction credits in return, a unilateral structure prevails whereby a company from a developing country finances the emission

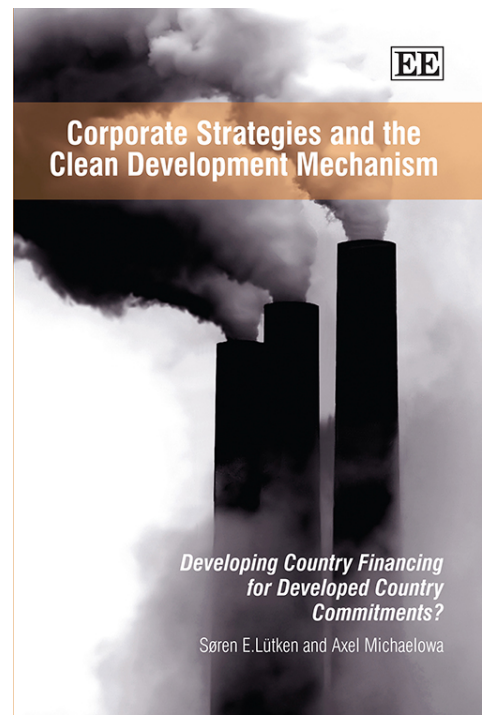
reduction project itself and sells the emission reduction credits. The book arrives at three fundamental, interconnected, conclusions: CDM is logically a unilaterally driven investment activity; CDM investment is an irrelevant compliance instrument for companies from industrialised countries and that this state of affairs is unlikely to change post 2012; and CDM thrives in less equal and less ambitious post-2012 climate regimes.

'This work provides a thoughtful and well-considered analysis of the emergence of the Clean Development Mechanism, its current status, and ways in which it may evolve. . The authors do a superb job. . Corporate Strategies and the Clean Development Mechanism is a timely and carefully crafted work. It deserves to be read by anyone interested in the past or possible futures for the CDM, and how it may link with a future international climate change regime.'

- Greg Picker, Climate Law

\section{$192 \mathrm{pp}$}

Hardback

9781847209283

590.00

$£ 81.00$

US\$134.00

US\$120.60
Edward Elgar Publishing Ltd. is registered in the UK at: The Lypiatts, 15 Lansdown Road, Cheltenham, Glos GL50 2JA. Registered number: 2041703

\section{How To Order}

\section{Online}

www.e-elgar.com

Get up to $20 \%$ discount when you order online

\section{By Email}

UK/ROW: sales@e-elgar.co.uk

N/S America: elgarsales@e-elgar.com

\section{By Phone}

UK/ROW: $\underline{+44}$ (ㅇ) 1243843291

N/S America: (00) 390-3149

\section{Connect With Us}

\section{Find us on Facebook}

facebook.com/EdwardElgarPublishing

\section{Follow us on Twitter}

For news, views and offers

@ElgarPublishing

\section{Read our Blog}

For news, views and debate from our authors and readers.

https://www.elgar.blog

\section{For More Information}

UK/ROW: info@e-elgar.co.uk

N/S America: elgarinfo@e-elgar.com 